\title{
TERAMPIL
}

Jurnal Pendidikan dan Pembelajaran Dasar

\section{MOTIVASI ORANG TUA MEMASUKKAN PUTRANYA KE SEKOLAH SEPAKBOLA SELABORA DI FAKULTAS ILMU KEOLAHRAGAAN UNIVERSITAS NEGERI YOGYAKARTA YUDESTA ERFAYLIANA}

Email: yudesta_89@yahoo.com Jurusan PGMI Fakultas Tarbiyah dan Keguruan UIN Raden Intan Lampung Volume 5 Nomor 2, Desember 2018

\begin{abstract}
Abstrak
Penelitian ini bertujuan untuk mengetahui seberapa besar motivasi orang tua memasukkan putranya ke sekolah sepakbola Selabora di Fakultas Ilmu Keolahragaan Universitas Negeri Yogyakarta. Penelitian ini merupakan penelitian deskriptif kuantitatif dengan menggunakan satu variabel, yaitu motivasi orang tua. Metode yang digunakan menggunakan metode survei. Populasi yang digunakan dalam penelitian ini adalah orang tua atau wali murid dari siswa di sekolah sepakbola selabora FIK UNY. Penelitian menggunakan sampel sebanyak 84 orang tua atau wali murid dari siswa di sekolah sepakbola selabora FIK UNY dari sampel yang diambil secara sampling insidental. Instrumen yang digunakan untuk mengumpulkan data adalah angket. Untuk menganalisis data yang terkumpul, peneliti menggunakan teknik analisis statistik deskriptif kuantitatif dengan persentase. Hasil penelitian menunjukkan bahwa rerata yang diperoleh sebesar 139,37 yang berada pada interval 133,69 s.d 144,78. Dengan hasil keseluruhan sebanyak 9 orang $(10,71 \%)$ orang tua masuk katagori sangat tinggi, sebanyak 15 orang $(17,86 \%)$ orang tua masuk katagori tinggi, sebanyak 36 orang $(42,86 \%)$ orang tua masuk katagori sedang, sebanyak 18 orang $(21,43 \%)$ orang tua masuk katagori rendah dan sebanyak 6 orang $(7,14 \%)$ orang tua masuk katagori sangat rendah. Berdasarkan hasil penelitian di atas dapat di simpulkan bahwa motivasi orang tua memasukkan putranya ke sekolah sepakbola Selabora di Fakultas Ilmu Keolahragaan Universitas Negeri Yogyakarta berada dalam kategori sedang sebanyak 36 orang tua $(42,86 \%)$.
\end{abstract}

Kata Kunci: Motivasi, Orang Tua, SSB Selabora

Motivasi orang tua memasukkan putranya ke sekolah sepakbola selabora di fakultas ilmu keolahragaan Universitas negeri yogyakarta 


\section{A. PENDAHULUAN}

Sepakbola merupakan salah satu olahraga yang paling terkenal di dunia. Permainan olahraga ini mudah dimainkan oleh siapa saja, menarik minat berbagai kelompok umur, berbagai tingkat keterampilan, dan pria maupun wanita memainkan olahraga ini di dalam atau di luar ruangan untuk rekreasi juga sebagai ajang persaingan. Permainan sepakbola sekarang ini telah berkembang pesat dikalangan masyarakat. Permainan olahraga sepakbola harus dimainkan oleh dua regu atau kesebelasan sehingga permainan ini merupakan permainan cepat yang membutuhkan gerak reflek yang baik dan tingkat kebugaran yang tinggi. Pemain sepakbola juga dapat mengambil keuntungan dari permainan ini, yaitu dari segi sosial, hiburan, dan mental. Bermain sepakbola juga dapat menjalin silahturahmi sesama teman. Tujuan dalam permainan sepakbola adalah memasukkan bola ke gawang lawan sebanyak-banyaknya dan berusaha mempertahankan gawangnya agar tidak kebobolan oleh lawan. Permainan ini juga tidak lepas dari kerjasama tim. Dengan pembelajaran pendidikan jasmani, tidak hanya kebugaranlah yang mereka peroleh melainkan hobi dan bakat dari masing-masing siswa juga dapat berkembang.

Perkembangan sepakbola di negara Indonesia merupakan permainan rakyat yang menyebar di seluruh pelosok tanah air. Dengan demikian, olahraga sepakbola sangat populer di Indonesia. Meskipun sepakbola sudah merakyat sampai pelosok daerah, namun prestasi yang dibanggakan dalam sepakbola tidak pernah menggembirakan bahkan lama kelamaan kelihatan prestasinya seperti menurun. Di tingkat Asia saja Indonesia masih tertinggal dari negara tetangga seperti Malaysia. Apalagi ditingkat dunia prestasi olahraga sepakbola bisa dikatakan jauh tertinggal belum bisa menunjukan prestasi yang menggembirakan buat rakyat Indonesia.

Melihat situasi kondisi yang ada pada saat ini tidak terlepas dari sistem pembinaan sepakbola yang ada di Indonesia. Seperti diketahui bahwa keberhasilan prestasi puncak dalam cabang olahraga sepakbola tidak terlepas dari peranan pembinaan sejak usia dini. Pembinaan yang dilakukan dari usia dini salah satunya melalui sekolah sepakbola (SSB). SSB merupakan wadah pembinaan sepakbola sejak usia dini. Hal ini dapat terlihat setiap sekolah sepakbola selalu dibanjiri oleh siswa. Dengan kejadian seperti ini merupakan fenomena yang bagus dalam peningkatan prestasi sepakbola dikancah nasinal melalui sekolah sepakbola.

Dalam proses pembinan usia dini dalam cabang olahraga sepakbola banyak terdapat SSB guna mengembangkan bakat yang dimiliki oleh setiap anak. Disinilah peran orang tua sangat penting dalam mengarahkan anak didiknya dalam menekuni suatu cabang olahraga. Banyak orang tua yang memasukan anaknya di SSB yang terkenal atau mempunyai daya tarik tersendiri.

Di Daerah Istimewa Yogyakarta banyak terdapat SSB yang bertujuan untuk membina pemain-pemain sepakbola yang bagus sejak usia dini. 
SSB yang ada di Daerah Istimewa Yogyakarta, diantaranya yang berada di wilayah Kota Madya Yogyakarta terdiri dari: SSB HW Yogyakarta, SSB MAS, SSB Gama, SSB Mataram Muda, SSB Selabora dan lain-lain. Di wilayah Kabupaten Sleman terdiri dari: SSB KKK Klajoran, SSB AMS, SSB Orsena, SSB Panji Putra, SSB Satria Pandawa dan lain-lain. Di Kabupaten Bantul terdiri dari: SSB Persiba, SSB Baturetno, SSB Tunas Melati, SSB Melati Muda, SSB Porak Jaya dan lain-lain. Di Kabupaten Kulun Progo diantaranya terdiri dari: SSB Halilintar, SSB PSST, SSB SGR, SSB Orae Brow, SSB HW Kulon Progo dan lain-lain. Sedangkan di wilayah Kabupaten Gunung Kidul di antaranya terdiri dari: SSB Handayani, SSB Rajawali, SSB Mandala Putra, SSB Angkasa Muda, SSB Dhaksinarga dan lain-lain. Dengan banyaknya jumlah SSB yang ada di Yogyakarta, bisa dikatakan bahwa banyak siswa yang ingin mendalami permainan olahraga sepakbola sejak usia dini.

Berdasarkan banyaknya jumlah SSB yang ada di Daerah Istimewa Yogyakarta, peneliti tertarik pada perkembangan SSB Selabora FIK UNY yang berada di wilayah Kota Madya Yogyakarta, yaitu SSB Selabora di Fakultas Ilmu Keolahragaan Universitas Negeri Yogyakarta yang akan di jadikan tempat penelitian tentang motivasi yang mempengaruhi orang tua memasukkan putranya ke SSB Selabora Fakultas Ilmu Keolahragaan Universitas Negeri yogyakarta. Hal ini dapat dilihat ketika SSB Selabora yang ada di bawah naungan Fakultas Ilmu
Keolahragaan Universitas Negeri Yogyakarta banyak diminati oleh banyak peserta. Berdasarkan hasil wawancara awal yang dilakukan oleh peneliti dengan pengurus SSB Selabora, diperoleh informasi tentang pengelompokan dan proses latihan dalam satu minggu. Pengelompokan umur diantaranya: umur 6-8 tahun, 810 tahun, 11-12 tahun, 13-14 tahun, dan 14-16 tahun dengan jumlah peserta secara keseluruhan 150 orang siswa. Sedangkan untuk jumlah latihan dilakukan sebanyak 3 kali dalam satu Minggu dan latihan dilaksanakan pada hari Senin, Kamis, dan Sabtu. Latihan dimulai pukul 15.00-17.00 WIB di lapangan FIK UNY.

SSB Selabora merupakan salah satu dari SSB yang ada di Daerah Istimewa Yogyakarta yang tergolong mempunyai prestasi yang cukup baik. Diantaranya prestasi yang di dapat SSB Selabora adalah mendapat juara 1 piala bergilir KONI Sleman tahun 2003, pada tahun 2004 mendapat juara 4 piala Bupati Sleman, dan mendapat juara 3 di kelompok umur 15 tahun dalam mengikuti kompetisi pengcab DIY yang diselenggarakan pada tahun 2010. Dengan adanya hasil prestasi yang di dapat oleh SSB Selabora tentu dapat dikatakan bahwa SSB Selabora tidak kalah kualitasnya dengan SSB yang ada di Daerah Istimewa Yogyakarta dalam perkembangan prestasi.

Metode latihan yang diterapkan di SSB selabora bisa jadi berbeda dengan SSB lainnya. Hal ini bisa dilihat dari proses selama latihan berlangsung. Selain itu lingkungan merupakan salah satu pendukung terciptanya suatu keberhasilan dalam 
setiap SSB. SSB Selabora mempunyai daya tarik tersendiri dikarenakan lingkungannya mudah dijangkau dengan transportasi dan berada di sekitar kampus Fakultas Ilmu Keolahragaan Universitas Negeri Yogyakarta.

Pelatih dan pengurus SSB merupakan salah satu sosok yang menentukan dalam proses terciptanya suatu keberhasilan prestasi dalam organisasi SSB. Setiap SSB hendaknya memiliki pelatih yang sudah berlisensi. Keberhasilan atau kegagalan pemain pada usia dini salah satunya dipengaruhi oleh kemampuan dirinya sendiri (atlet) dan dukungan kemampuan pelatih. Seorang pelatih harus mengetahui perkembangan siswanya baik dari segi kondisi fisik atau kebugaran jasmani, keterampilan teknik dasarnya, serta aspek sosial maupun aspek mental. Selain itu pengelompokan umur sangatlah penting pada pembinaan usia dini. Hal ini dikarenakan pada anak terjadi proses perubahan dalam segi fisik, psikis, dan sosial.

Banyaknya siswa SSB Selabora merupakan salah satu indikator bahwa anak-anak maupun orang tua cukup tertarik memasukkan putranya ke SSB Selabora di Fakultas Ilmu Keolahragaan Universitas Negeri Yogyakarta. Selain itu, hal ini dapat dilihat pada saat berlatih maupun bertanding banyak di antara orang tua tersebut banyak yang menunggui dan memberikan motivasi kepada anaknya. Berdasarkan hal tersebut, maka timbul suatu permasalahan yang perlu diangkat dalam suatu penelitian yang berkaitan dengan motivasi orang tua dalam memasukkan putranya ke SSB
Selabora. Berdasrakan kondisi tersebut, peneliti tertarik untuk mengambil data di SSB Selabora yang berada di Fakultas Ilmu Keolahragaan Universitas Negeri Yogyakarta guna dijadikan objek atau tempat penelitian. Oleh karena itu, peneliti berusaha mencari fakta yang ada di lapangan untuk dapat diambil kesimpulan terhadap seberapa besar motivasi orang tua memasukkan putranya ke SSB Selabora yang ada di Fakultas Ilmu Keolahragaan Universitas Negeri Yogyakarta tersebut.

B. KAJIAN TEORITIK

1. Hakikat Motiv Dan Motivasi

Motif merupakan hal yang penting dalam manusia berbuat. (Bimo Walgito, 2004: 152) Menurut pendapat lain Motif adalah segala sesuatu yang mendorong seseorang untuk bertindak melakukan sesuatu. (M. Ngalim Purwanta, 2010: 60), Dalam psikologi umum, kita mengetahui bahwa motif merupakan suatu dorongan atau suatu kehendak yang mendasari munculnya suatu tingkah laku. Jadi, motivasi dapat diartikan sebagai suatu kekuatan atau tenaga pendorong untuk melakukan suatu hal atau menampilkan sesuatu perilaku tertentu.

Pada dasarnya setiap perilaku dari individu didorong oleh satu kekuatan. Baik yang di dapat di dalam individu maupun luar individu seseorang. Dorongan yang menggerakan perilaku individu dikenal dengan istilah motif. Motif adalah daya pendorong atau suatu tenaga di dalam diri manusia yang menyebabkan menusia bertindak dengan cara tertentu. 
Menurut pendapat Herman Subardjah motif adalah suatu rangsangan atau suatu dorongan yang terdapat dalam diri manusia yang secara aktif mendorong manusia untuk berbuat sesuatu dengan tingkah laku untuk memenuhi kebutuhan hidupnya. (Herman Subardjah, 2000: 20), Termotivasinya seseorang untuk berbuat tergantung pada besar kecilnya motif. Motivasi disini diartikan sebagai proses yang menggerakkan seseorang hingga berbuat sesuatu. Sudibyo Setyobroto mengemukakan bahwa motif adalah sumber penggerak dan pendorong tingkah-laku individu memenuhi kebutuhan untuk mencapai tujuan tertentu. (Sudibyo Setyobroto, 1989: 24)

Menurut pendapat ahli Husdarta (2011: 32), menyimpulkan bahwa motif adalah suatu rangsangan atau suatu dorongan yang terdapat dalam diri manusia untuk berbuat sesuatu dengan tingkah laku untuk memenuhi kebutuhan hidupnya. Termotivasinya seseorang untuk berbuat tergantung pada besar kecilnya motif. Istilah motivasi mengacu kepada faktor dan proses yang mendorong seseorang untuk bereaksi atau tidak bereaksi dalam berbagai situasi. Motif diartikan sebagai sesuatu kekuatan yang terdapat dalam diri organisme, yang menyebabkan organisme itu bertindak, maka kebutuhan dan keinginan itu dikatakan motif.

Berdasarkan hal di atas, dapat dikatakan motif sebagai suatu kondisi. Kondisi ini merupakan kekuatan atau dorongan yang menggerakkan organisme untuk mencapai suatu tujuan atau seberapa tujuan tingkat tertentu. Jadi, dengan kata lain motif menyebabkan timbulnya suatu kekuatan agar individu itu berbuat dan bertingkah laku. Motif merupakan sumber kekuatan pendorong yang tidak akan pernah terlepaskan dari kehidupan manusia dalam bertingkah laku dan mendorong untuk berbuat, bertindak, bertingkah laku, untuk memenuhi tuntutan atau tujuan yang dikehendaki.

Menurut Iskandar motivasi berpangkal dari kata motif yang dapat diartikan sebagai daya penggerak yang ada di dalam diri seseorang untuk melakukan aktivitas-aktivitas tertentu demi tercapainya suatu tujuan. Bahkan motif dapat diartikan sebagai suatu kondisi interen (kesiapsiagaan). (Iskandar, 2009: 184), Sedangkan menurut Hamzah B. Uno, dalam bukunya teori motivasi dan pengukurannya mengatakan bahwa motivasi adalah dorongan dasar yang menggerakakan seseorang bertingkah laku. Dorongan ini ada pada diri seseorang yang menggerakkan untuk melakukan sesuatu yang sesuai dengan dorongan dalam dirinya. (Hamzah B. Uno, 2007: 1)

Pengertian motivasi lebih cenderung menjelaskan hal-hal yang bersifat umum dan menunjukkan proses secara keseluruhan termasuk situasi yang mendorong seseorang dalam bertindak. Husdarta mengatakan bahwa motivasi adalah energi psikologis yang bersifat abstrak. Motivasi pada dasarnya adalah kondisi mental yang mendorong dilakukannya suatu tindakan dan memberikan kekuatan yang mengarah kepada pencapaian kebutuhan, memberikan kepuasan, 
ataupun mengurangi ketidak seimbangan. (Husdarta, 2011: 31)

Berdasarkan teori batasan motivasi dan motif dimuka, maka dapat disimpulkan bahwa motivasi dan motif itu berbeda. Sesuai pendapat yang dikatakan oleh Herman Subardjah bahwa, "Motif adalah daya penggerak dari dalam diri dan di dalam subjek untuk melakukan aktivitas-aktivitas tertentu demi mencapai tujuan. Motif merupakan suatu kondisi internal atau disposisi (kesiap-siagaan)." Motivasi adalah daya penggerak yang telah menjadi aktif. Motif menjadi aktif pada saatsaat tertentu bila kebutuhan untuk mencapai tujuan sangat dirasakan atau dihayati. (Herman Subardjah, 2000: 21)

Berdasarkan pendapat para ahli di atas, dapat disimpulkan bahwa motivasi adalah kekuatan, baik dalam diri maupun dari luar seseorang yang mendorong untuk bertingkah laku untuk mencapai tujuan. Dengan ini, diharapkan motivasi yang baik itu tumbuh dari dalam individu. Motivasi memiliki peranan yang sangat penting, sebab motivasi merupakan dasar untuk menggerakkan perbuatan dan perilaku seseorang. Demikian juga motivasi yang mempengaruhi orang tua untuk menyekolahkan putranya ke SSB Selabora di Fakultas Ilmu Keolahragaan Universitas Negeri Yogyakarta diharapkan berpengaruh positif agar dapat manghasilkan hasil yang memuaskan dan membantu kemajuan seoarang atlet sepakbola sejak usia dini dan membawa prestasi yang baik terhadap kemajuan sepakbola.

Motivasi dapat diartikan sebagai kekuatan (energi) seseorang yang dapat menimbulkan tingkat persistensi dan antusiasismenya dalam melaksanakan suatu kegitan, baik yang bersumber dari dalam diri individu itu sendiri (motivasi intrinsik) maupun dari luar individu (motivasi ekstrinsik). (Ratna Yudawati \& Dani Haryanto, 2011: 79). Menurut Singgih D Gunarsa, motivasi untuk melakuka sesuatu dapat datang dari diri sendiri, dikenal sebagai motivasi intrinsik, serta dapat pula datang dari lingkungan, atau disebut motivasi ekstrinsik. (Singgih D Gunarsa, 2004: 50)

Berdasarkan jenis motivasi yang dikemukakan di atas, dapat disimpulkan bahwa motivasi intrinsik adalah motivasi yang timbul dari dalam individu itu sendiri. Sedangkan motivasi ekstrinsik adalah dorongan yang tumbuh karena rangsangan dari luar dirinya untuk mencapai tujuan. Dengan demikian diharapkan motivasi yang baik tumbuh dari dalam diri individu. Demikian juga dengan motivasi orang tua yang menyekolahkan putranya ke SSB Selabora di Fakultas Ilmu Keolahragaan Universitas Negeri Yogyakarta, diharapkan tumbuh dari dalam diri orang tua sehingga akan berpengaruh positif. Untuk itu perlu diteliti keadaan yang sesungguhnya motivasi apa saja yang mendasari orang tua menyekolahkan putranya ke SSB Selabora di fakultas Ilmu Keolahragaan Universitas negeri yogyakarta.

Menurut Atkinson, menyatakan: "motivasi dibedakan menjadi tiga macam".

a. Motivasi berprestasi atau need for achievement yang disingkat $n$ achievement. 
b. Motivasi berkuasa atau need power yang disingkat n-power

c. Motivasi ber afialisasi atau need for affiliation yang disingkat $n$ affiliation. (Herman Subardjah, 2000: 45)

Berdasarkan teori di atas, maka dapat disimpulkan bahwa pada hakekatnya motivasi mempunyai makna sebagai sesuatu kekuatan atau sumber penggerak yang menyebabkan seseorang terdorong untuk melakukan suatu kegiatan aktivitas tertentu dalam rangka mencapai tujuan. Pada dasarnya tingkahlaku bermotivasi akan terus berlangsung selama tujuan yang diharapkan belum tercapai.

\section{Permainan Sepakbola}

Sepakbola merupakan permainan beregu yang setiap regu terdiri dari 11 pemain dan salah satunya adalah penjaga gawang. Permainan ini hampir seluruhnya dimainkan menggunakan tungkai atau kaki, kecuali penjaga gawang yang boleh menggunakan lengan atau tangannya di daerah hukumannya. Dalam perkembangannya permainan ini dapat dimainkan di luar lapangan dan di dalam ruangan tertutup, (Sucipto. dkk, 2000: 7).

Keterampilan teknik bermain sepakbola (Skill) adalah penerapan teknik dasar permainan sepakbola dalam bermain sepakbola. Permainan sepakbola bertujuan untuk memasukkan bola ke gawang lawan sebanyak-banyaknya dan berusaha menjaga gawangnya agar tidak kebobolan oleh tim lawan. Permainan ini dilakukan oleh seluruh anggota badan kecuali kedua tangan, sedangkan untuk posisi penjaga gawang boleh melakukannya dengan seluruh anggota badan.

3. Teknik Dasar Kemampuan
Bermain Sepakbola

Menurut Sucipto dkk mengatakan bhwa untuk bermain sepakbola dengan baik pemain dibekali dengan teknik dasar yang baik. Beberapa teknik dasar yang dimiliki pemain sepakbola adalah menendang (kicking), menghentikan (stoping), menggiring (dribbling), menyundul (heading), merampas (tackling), lemparan kedalam (throw-in), dan menjaga gawang (goal keeping). (Sucipto dkk, 2000: 17)

\section{METODE PENELITIAN}

Penelitian ini merupakan penelitian deskriptif kuantitatif. Metode penelitian deskriptif kuantitatif dapat diartikan sebagai metode penelitian yang berlandaskan pada filsafat positivisme, digunakan untuk meneliti pada populasi atau sampel tertentu, pengumpulan data menggunakan instrumen penelitian, analisis data bersifat kuantitatif/statistik, dan merupakan penelitian non hipotesis sehingga dalam langkah penelitiannya tidak perlu merumuskan hipotesis. (Suharsimi Arikunto, 1996: 243)
1. Populasi dan Sampel Penelitian
a. Populasi Penelitian

Populasi merupakan keseluruhan objek yang akan diteliti. Populasi adalah wilayah generalisasi yang terdiri atas: objek atau subjek yang mempunyai kualitas dan karakteristik tertentu yang diterapkan oleh peneliti untuk dipelajari dan kemudian ditarik kesimpulan. (Sugiyono, 2009: 80) 
Populasi dalam penelitian ini adalah seluruh orang tua dan wali murid di siswa SSB Selabora Fakultas Ilmu Keolahragaan Universitas Negeri Yogyakarta yang berjumlah 150 orang. Data ini diperoleh dari salah satu pengurus SSB Selabora bagian administrasi yang bernama Ibu Sumini A.Md. Setelah diketahui besarnya populasi langkah selanjutnya adalah menentukan sampel yang akan diteliti.

b. Sampel Penelitian

Sampel adalah bagian dari jumlah dan karakteristik yang dimiliki oleh populasi tertentu. (Sugiyono, 2009: 81) Jadi yang dimaksud dengan sampel adalah sebagian atau wakil dari suatu populasi yang akan diambil.

Sampel yang digunakan dalam penelitian ini adalah sampel yang diambil secara purposive sampling. Sampel bersetujuan atau purposive sampling dilakukan dengan cara mengambil subjek bukan didasarkan atas adanya tujuan tertentu. Teknik ini biasanya dilakukan karena beberapa pertimbangan, misalnya alasan keterbatasan waktu, tenaga, dan dana sehingga tidak dapat mengambil sampel yang besar dan jauh. (Suharsimi Arikunto, 2006: 139) Penelitian ini dilakukan dengan memberikan angket sejumlah 130 lembar kepada orang tua siswa SSB Selabora di luar populasi yang sudah dijadikan sebagai sampel uji coba instrumen yaitu sebanyak 20 orang tua siswa.
2. Instrumen dan Teknik
Pengumpulan Data
a. Instrumen Penelitian

Instrumen adalah alat pada waktu peneliti menggunakan sesuatu motode. (Suharsimi Arikunto, 1993: 121) Instrumen pengumpulan data adalah alat bantu yang dipilih dan digunakan oleh peneliti dalam kegiatannya mengumpulkan agar kegiatan tersebut menjadi sistematis dan dipermudah olehnya. (Suharsimi Arikunto, 2005: 101) Instrumen yang digunakan dalam penelitian ini adalah kuesioner (angket). Kuesioner (angket) merupakan teknik pengumpulan data yang dilakukan dengan cara memberi seperangkat pertanyaan atau pernyataan tertulis kepada responden untuk dijawabnya. (Sugiyono, 2009: 142)

Ada tiga langkah yang harus ditempuh dalam menyusun instrumen angket, yaitu: a) mendefinisikan konstrak, b) menyidik faktor, c) menyusun butirbutir pertanyaan. (Sutrisno Hadi, 1991: 7) Berikut ini disajikan table mengenai kisi-kisi angket penelitian motivasi orang tua memasukkan putranya ke SSB Selabora di Fakultas Ilmu Keolahragaan Universitas Negeri Yogyakarta. 
Tabel 1.

Kisi-Kisi Angket Penelitian Motivasi Orang Tua Memasukkan Putranya Ke Sekolah Sepakbola Selabora Di Fakultas Ilmu Keolahragaan Universitas Negeri Yogyakarta

\begin{tabular}{|c|c|c|c|c|}
\hline \multirow{2}{*}{ Variabel } & \multirow{2}{*}{ Faktor } & \multirow{2}{*}{ Indikator } & \multicolumn{2}{|c|}{ No. Butir } \\
\hline & & & Positif & Negatif \\
\hline \multirow{6}{*}{$\begin{array}{c}\text { Motivasi } \\
\text { Orang } \\
\text { Tua }\end{array}$} & $\begin{array}{l}\text { Motivasi } \\
\text { Intrinsik }\end{array}$ & $\begin{array}{l}\text { 1. Pembawaan Atlet } \\
\text { 2. Tingkat Pendidikan } \\
\text { 3. Pengalaman Masa Lalu } \\
\text { 4. Cita-Cita dan Harapannya }\end{array}$ & $\begin{array}{l}1,2,4,5 \\
6,7,10,11 \\
12,14,15, \\
17 \\
18,19,22, \\
23\end{array}$ & $\begin{array}{l}3 \\
8,9 \\
13,16 \\
20,21\end{array}$ \\
\hline & Motivasi & 1. Fasilitas yang Tersedia & $24,26,27$ & 25,28 \\
\hline & EK & 2. Sarana dan Prasarana & $\begin{array}{l}29,30,32 \\
33\end{array}$ & 31,34 \\
\hline & & 3. Metode Latihan & $\begin{array}{l}35,37,38 \\
40\end{array}$ & 36,39 \\
\hline & & 4. Program Latihan & $41,42,44$ & 43,45 \\
\hline & & $\begin{array}{l}\text { 5. Lingkungan atau Iklim } \\
\text { Pembinaan }\end{array}$ & $46,47,50$ & 48,49 \\
\hline
\end{tabular}

Sumber: (H. J. S. Husdarta. 2011: 40)

1) Konsultasi / Kalibrasi Ahli (Expert Judgement)

Setelah butir-butir pernyataan tersusun, langkah selanjutnya adalah mengkonsultasikan pada ahli atau kalibrasi ahli. Ahli tersebut berjumlah 3 orang dengan bidang yang bersangkutan, diantaranya yang terdiri dari bapak Amat Komari M. Si, Komarudin M.A, Yudanto M.Pd serta dosen pembimbing bapak Fathan Nurcahyo M.Or.

2) Uji Coba Instrumen

Uji coba dilakukan dengan sampel sebanyak 20 dan diberikan kepada orang tua yang memasukkan putranya ke SSB Selabora melalui putranya yang mengikuti jadwal latihan di SSB Selabora. Waktu pelaksanaan pengambilan uji coba dilaksanakan pada hari Senin tanggal 19 Desember 2011 dan pada waktu penarikan angket uji coba pada hari Kamis tanggal 22 Desember 2011. Uji coba angket perlu dilakukan agar dapat memberikan kesempatan kepada responden untuk memberikan saran-saran bagi koesioner yang diuji cobakan tersebut. (Suharsimi Arikunto, 1993: 196)

a) Uji Validitas Instrumen (tingkat kesahian butir)

Uji validitas instrumen terhadap konsep yang diukur benar-benar mengukur apa yang seharusnya diukur. Validitas berkaitan dengan ketepatan tes terhadap konsep, objek atau variabel yang hendak diukur sehingga mengukur atau mengevaluasi apa yang semestinya diukur. (Wahjoedi, 2000: 28) 
Validitas adalah suatu ukuran yang menunjukkan tingkat-tingkat kevalidan atau kesahihan sesuatu instrumen tertentu. Suatu instrumen yang valid atau sahih mempunyai validitas yang tinggi. Uji validitas atau kesahihan butir harus melalui beberapa langkah sebelum menyatakan bahwa butir instrumen tersebut sahih atau gugur. (Suharsimi Arikunto, 1993: 136) Sutrisno Hadi menyatakan untuk menguji kesahihan butir dikotomi antara lain dengan uji t, korelasi dwiserial atau korelasi momen tangkar. (Sutrisno Hadi, 1991: 34) Uji signifikansi butir atau item dinyatakan valid jika $r_{x y}$ tabel tarif signifikan 5\%. Adapun untuk mengukur validitas angket sebagai instrumen menggunakan rumus korelasi momen tangkar dengan person sebagai berikut:

Korelasi product moment (Sutriso Hadi, 1991: 34)

$\mathrm{r}_{\mathrm{xy}}=\frac{N \sum X Y-\left(\sum X\right)\left(\sum Y\right)}{\sqrt{\left\{N \sum X^{2}-\left(\sum X\right)^{2}, \hat{X} N \sum Y^{2}-\left(\sum Y\right)^{2}\right\}}}$

Keterangan :

$\mathrm{r}_{\mathrm{xy}} \quad$ : korelasi momen tangkar

$\mathrm{N} \quad$ : cacah subjek uji coba

Tabel 2.

Kisi-Kisi Hasil Uji Coba Instrumen Angket Penelitian Motivasi Orang Tua Memasukkan Putranya Ke Sekolah Sepakbola Selabora Di Fakultas Ilmu Keolahragaan Universitas Negeri Yogyakarta

\begin{tabular}{|c|c|c|c|c|c|}
\hline \multirow{2}{*}{ Variabel } & \multirow{2}{*}{ Faktor } & \multirow{2}{*}{ Indikator } & \multicolumn{2}{|c|}{ No. Butir } & \multirow{2}{*}{$\begin{array}{l}\text { Nomor } \\
\text { Gugur }\end{array}$} \\
\hline & & & Positif & Negatif & \\
\hline $\begin{array}{c}\text { Motivasi } \\
\text { Orang } \\
\text { Tua }\end{array}$ & $\begin{array}{l}\text { Motivasi } \\
\text { Intrinsik }\end{array}$ & $\begin{array}{l}\text { 1. Pembawaan } \\
\text { Atlet } \\
\text { 2. Tingkat } \\
\text { Pendidikan } \\
\text { 3. Pengalaman } \\
\text { Masa Lalu } \\
\text { 4. Cita-Cita dan }\end{array}$ & $\begin{array}{l}1,2,4,5 \\
6,7,10,11 \\
12,14,15, \\
17 \\
18,19,22,\end{array}$ & $\begin{array}{l}3 \\
8,9 \\
13,16 \\
20,21\end{array}$ & 20 \\
\hline
\end{tabular}

Motivasi orang tua memasukkan putranya ke sekolah sepakbola selabora di fakultas ilmu keolahragaan Universitas negeri yogyakarta $\sum X \quad$ : sigma/jumlah $\mathrm{X}$ skor (skor butir)

$\sum X^{2}:$ sigma $X$ kuadrat

$\sum Y \quad$ : sigma/jumlah $\mathrm{Y}$ (skor

$\sum \mathrm{Y}^{2}:$ sigma $\mathrm{Y}$ kuadrat

$\sum X Y$ : sigma tangkar (perkalian $X$ dan Y). (Sutrisno Hadi.1991: 34)

Berdasarkan hasil analisis, dari 50 item diperoleh butir gugur sebanyak 5 butir yaitu nomor 8, 20, 37, 45, dan 48. Item ini dinyatakan gugur karena apabila peluang kesalahan jika $\mathrm{P} \leq$ 0,05 maka dikatakan valid. Tapi jika $\mathrm{P} \geq 0,05$ maka tidak valid. Karena dalam penelitian tentang motivasi orang tua memasukkan putranya ke SSB Selabora di Fakultas Ilmu Keolahragaan Universitas Negeri Yogyakarta termasuk dalam kategori penelitian sosial. Jadi peluang kesalahan yang digunakan sebanyak $5 \%$. Ke lima butir yang gugur tidak digunakan dalam angket penelitian. Karena apabila digunakan akan menimbulkan bias pada penelitian, sehingga penelitian menyisihkan ke lima item tersebut. Untuk lebih jelas dapat dilihat dalam tabel 2 berikut ini: 


\begin{tabular}{|c|c|c|c|c|c|}
\hline & & Harapannya & 23 & & \\
\hline & $\begin{array}{l}\text { Motivasi } \\
\text { Ekstrinsik }\end{array}$ & $\begin{array}{l}\text { 5. Fasilitas yang } \\
\text { Tersedia } \\
\text { 6. Sarana dan } \\
\text { Prasarana } \\
\text { 7. Metode Latihan } \\
\text { 8. Program } \\
\text { Latihan } \\
\text { 9. Lingkungan } \\
\text { atau Iklim } \\
\text { Pembinaan }\end{array}$ & $\begin{array}{l}24,26,27, \\
29,30,32, \\
33 \\
35,37,38, \\
40 \\
41,42,44 \\
46,47,50\end{array}$ & $\begin{array}{l}25,28 \\
31,34 \\
36,39 \\
43,45 \\
48,49\end{array}$ & $\begin{array}{l}37 \\
45 \\
48\end{array}$ \\
\hline Jumlah & & & \multicolumn{2}{|c|}{50} & 5 \\
\hline
\end{tabular}

b) Uji Reliabilitas Instrumen

Uji reabilitas dilakukan untuk mengetahui keadaan instrumen atau alat ukur. Suatu alat ukur dinyatakan reliabel jika alat tersebut menghasilkan hasil konsisten sehingga instrumen ini dapat dipakai dengan aman karena dapat bekerja dengan baik pada waktu yang berbeda. Reliabilitas menunjuk pada satu pengertian bahwa suatu instrumen cukup dapat dipercaya untuk digunakan sebagai alat pengumpul data karena instrumen tersebut sudah baik. (Suharsimi Arikunto, 1993: 142) Pengujian reliabilitas dengan teknik Alpha dilakukan untuk jenis data angket atau bentuk uraian. (Suharsimi arikunto, 1993:167)

Rumus untuk menentukan reliabilitas dalam penelitian ini menggunakan rumus Alpha Cronbarch (Suharsimi Arikunto 1993: 167), adapun rumus tersebut sebagai berikut :

$\mathrm{r}_{11}=\left(\begin{array}{c}\mathrm{k} \\ \underline{1-} \\ (\mathrm{k}-1)\end{array}\right)\left(\begin{array}{l}\sum \sigma_{b}^{2} \\ - \\ \sigma^{2} \mathrm{t}\end{array}\right)$
Keterangan:

$\mathrm{r}_{11} \quad:$ Reliabilitas instrumen

k : Banyaknya butir pertanyaan/ banyaknya soal

$\sum \sigma_{b}^{2}:$ Jumlah Variabel Butir

$\sigma_{t}^{2}$ : Varians Total (Suharsimi Arikunto. 1993: 167)

Berdasarkan hasil yang diperoleh setelah melakukan uji reliabilitas instrumen motivasi dengan menggunakan komputer Seri Program Statistik (SPS), memperoleh harga rtt 0,938 untuk faktor instrinsik dan 0,937 untuk faktor ekstrinsik, dengan demikian hasil analisis tersebut menunjukkan bahwa instrumen dinyatakan andal, hal ini menunjukkan bahwa instrumen tersebut dapat digunakan sebagai alat ukur pengumpul data. Hasil selengkapnya dapat dilihat dilampiran.

Tabel 3.

Hasil Analisis Reliabilitas Instrumen

\begin{tabular}{llll}
\hline Variabel & Faktor & rtt & Status
\end{tabular}

Motivasi Instrinsik 0,938 Andal

Ekstrinsik 0,937 Andal 


\section{d. Teknik Pengumpulan Data}

Teknik pengumpulan data dalam penelitian ini menggunakan angket (kuisioner). Angket yang digunakan adalah angket tipe pilihan yang meminta responden memilih jawaban yang sudah ditentukan. Alternatif jawaban dalam angket ini ditetapkan skor yang diberikan untuk masingmasing pilihan dengan menggunakan skala likert. Penskoran digunakan dengan menggunakan skala Likert. Skala likert merupakan skala yang berisi lima tingkat jawaban mengenai kesetujuan responden terhadap statemen atau pernyataan yang dikemukakan mendahului opsi jawaban yang disediakan. (Sutrisno Hadi, 1991: 19)

Modifikasi skala likert dimaksudkan untuk menghilangkan kelemahan yang dikandung oleh skala lima tingkat. Dengan empat alternatif jawaban, yaitu: sangat setuju (SS), setuju (S), tidak setuju (TS), dan sangat tidak setuju (STS). Skala likert digunakan untuk mengukur sikap, pendapat, dan persepsi seseorang atau kelompok orang tentang fenomena sosial (Sugiyono, 2009: 93). Jawaban setiap item instrumen yang menggunakan skala likert mempunyai gradasi dari sangat positif sampai sangat negative yang berupa kata-kata, sanga setuju, setuju, tidak setuju, sangat tidak setuju.

Tabel. 4

Skor Alternatif Jawaban Angket

$\begin{array}{cc}\text { Jenis } \\ \text { Alternatif Jawaban } & \text { Pertanyaan }\end{array}$

$\begin{array}{lll} & + & - \\ \text { Sangat Setuju (SS) } & 4 & 1 \\ \text { Setuju (S) } & 3 & 2\end{array}$

Tidak Setuju (TS) $\quad 2 \quad 3$

Sangat Tidak Setuju $1 \quad 4$

(STS)

(Sugiyono, 2009: 93)

\section{Teknik Analisis Data}

Teknik analisis data yang akan digunakan dalam penelitian ini adalah menggunakan statistik deskriptif. Adapun teknik penghitungannya untuk masingmasing butir dalam angket menggunakan persentase. Menurut Anas sudijono digunkan rumus sebagai berikut:

$$
P=\frac{F}{N} \times 100 \%
$$

Keterangan:

$$
\begin{aligned}
& \mathrm{P} \text { : Angka persentase (\%) } \\
& \mathrm{F} \text { : Frekuensi yang sedang } \\
& \text { dicari presentasenya } \\
& \mathrm{N} \text { : Jumlah frekuensi atau } \\
& \text { banyaknya individu. (Anas } \\
& \text { Sudijono. 2006: 43) }
\end{aligned}
$$

Untuk membuat katagori pengelompokan, harus mengetahui besarnya nilai rata-rata hitung (mean diberi lambang $M$ ) dan besaran standar deviasi (SD) dari skor yang diperoleh. Menurut Anas Sudijiono, rumus yang digunakan adalah sebagai berikut:

1. $M+1,5$ SD Sangat Tinggi

2. $M+0,5$ SD s.d $M+1,5$ SD Tinggi

3. $\mathrm{M}-0,5$ SD s.d $\mathrm{M}+0,5 \mathrm{SD}$ Sedang

4. $\mathrm{M}-1,5$ SD s.d $\mathrm{M}-0,5$ SD Rendah

5. M - 1,5 SD ke bawah Sangat Rendah (Anas Sudijono. 2006: 175) 


\section{HASIL PENELITIAN DAN PEMBAHASAN}

\begin{abstract}
Setelah data penelitian terkumpul dilakukan analisis dengan menggunakan teknik analisis deskriptif kuantitatif dengan persentase menggunakan bantuan computer program SPSS versi 17.0 for windows. Dari analisis data tersebut diperoleh skor terendah (minimum) 116 ,skor tertinggi (maksimum) 164, rerata (mean) 139,37, nilai tengah (median) 139,00, nilai yang sering muncul (mode) 139, standar defiasi (SD) 10,82. Hasil analisis datannya tabel adalah:
\end{abstract}

Tabel 5.

Hasil Analisis Data Motivasi Secara Keseluruhan

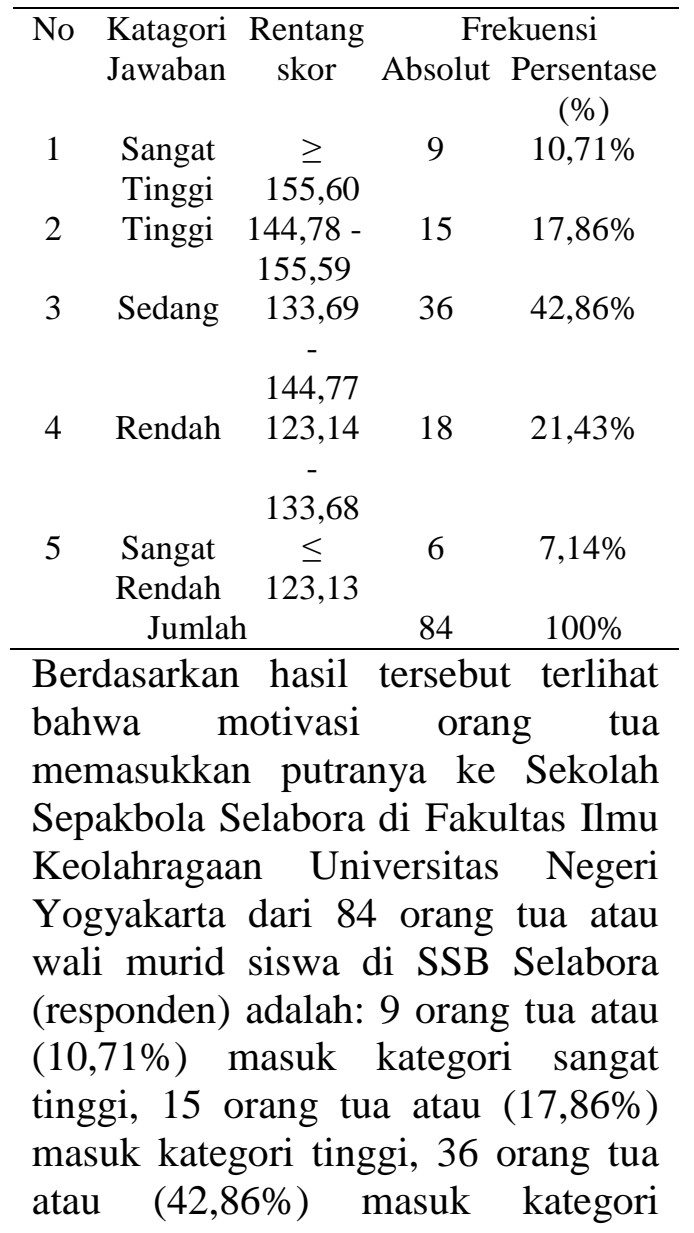

sedang, 18 orang tua atau $(21,43 \%)$ masuk kategori rendah dan 6 orang tua atau $(7,14 \%)$ masuk kategori sangat rendah.

Adapun jika digambarkan dalam bentuk diagram batang hasil penelitian dapat dilihat sebagai berikut:

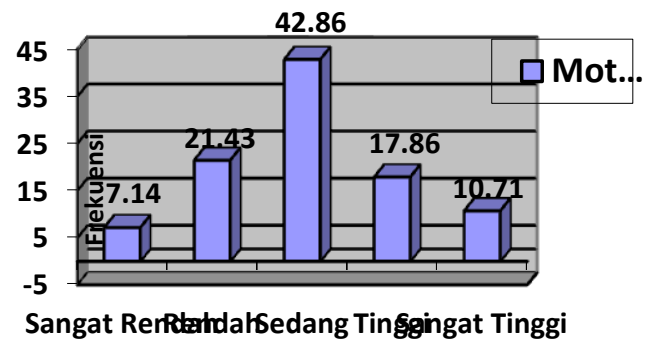

Katagori

Gambar 3. Diagram Batang Motivasi Orang Tua Memasukkan Putranya ke Sekolah Sepakbola Selabora di Fakultas Ilmu Keolahragaan Universitas Negeri Yogyakarta

Hasil penelitian menunjukkan bahwa motivasi orang tua memasukkan putranya ke Sekolah Sepakbola Selabora di Fakultas Ilmu Keolahragaan Universitas Negeri Yogyakarta sebagian besar berada dalam katagori "sedang" dengan rerata yang diperoleh sebesar 139,37 yang berada pada interval 133,69 s.d 144,78 dengan frekwensi sebanyak 36 responden $(42,86 \%)$.

Berikut disajikan analisis data berdasarkan data pada tiap-tiap faktor, yang terdiri dari dua faktor yaitu faktor intrinsik dan faktor ekstrinsik.

\section{Faktor Intrinsik}

Berdasarkan data faktor intrinsik terdapat 21 peryataan dengan skor 21 - 84. Dari analisis data dalam faktor 
intrinsik diperoleh skor terendah (minimum) 49, skor tertinggi (maksimum) 78, rerata (mean) 66,13, nilai tengah (median) 66,00, nilai yang sering muncul (mode) 69, standar defiasi (SD) 6,03.

\section{Tabel 6.}

Hasil Analisis Data Berdasarkan Faktor Intrinsik

\begin{tabular}{|c|c|c|c|c|}
\hline \multirow[t]{2}{*}{ No } & Katagori & Rentang & \multicolumn{2}{|c|}{ Frekuensi } \\
\hline & Jawaban & skor & Absolut & $\begin{array}{c}\text { Persentase } \\
(\%)\end{array}$ \\
\hline 1 & $\begin{array}{l}\text { Sangat } \\
\text { Tinggi }\end{array}$ & $\geq 75,18$ & 3 & $3,57 \%$ \\
\hline 2 & Tinggi & $\begin{array}{c}69,15- \\
75,17\end{array}$ & 22 & $26,19 \%$ \\
\hline 3 & Sedang & $\begin{array}{c}63,12- \\
69,14\end{array}$ & 31 & $36,90 \%$ \\
\hline 4 & Rendah & $\begin{array}{c}57,08- \\
63,11\end{array}$ & 22 & $26,19 \%$ \\
\hline 5 & $\begin{array}{l}\text { Sangat } \\
\text { Rendah } \\
\text { Jumlah }\end{array}$ & $\begin{array}{c}\leq \\
57,07\end{array}$ & 84 & $7,14 \%$ \\
\hline
\end{tabular}

Berdasarkan hasil tersebut terlihat bahwa melalui faktor intrinsik motivasi orang tua memasukkan putranya ke Sekolah Sepakbola Selabora di Fakultas Ilmu Keolahragaan Universitas Negeri Yogyakarta dari 84 orang tua atau wali murid siswa di SSB Selabora adalah: 3 orang tua atau $(3,57 \%)$ masuk kategori sangat tinggi, 22 orang tua atau $(26,19 \%)$ masuk kategori tinggi, 31 orang tua atau $(36,90 \%)$ masuk kategori sedang, 22 orang tua atau $(26,19 \%)$ masuk kategori rendah dan 6 orang tua atau $(7,14 \%)$ masuk kategori sangat rendah.
Adapun jika digambarkan dalam bentuk diagram batang hasil penelitian dapat dilihat sebagai berikut:

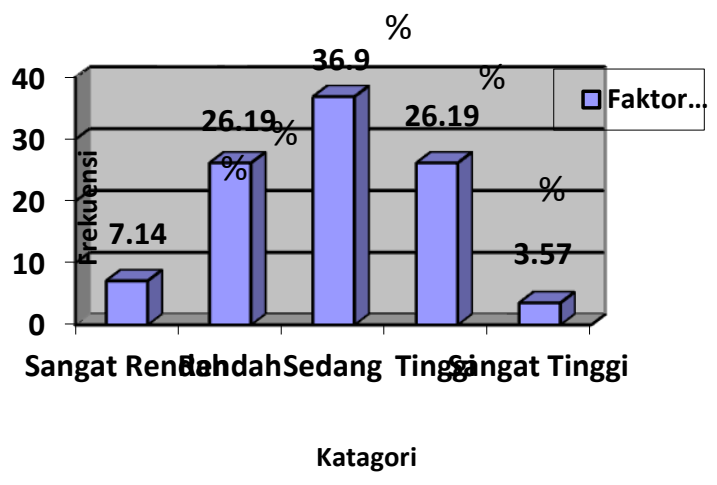

Gambar 4. Diagaram Batang Motivasi Orang Tua Memasukkan Putranya ke Sekolah Sepakbola Selabora di Fakultas Ilmu Keolahragaan Universitas Negeri

$$
\text { Yogyakarta }
$$$$
\text { Faktor Intrinsik }
$$

Hasil penelitian menunjukkan bahwa motivasi orang tua memasukkan putranya ke Sekolah Sepakbola Selabora di Fakultas Ilmu Keolahragaan Universitas Negeri Yogyakarta melalui faktor intrinsik sebagian besar berada dalam katagori "sedang" dengan rerata yang diperoleh sebesar 66,13 yang berada pada interval 63,12 s.d 69,14 dengan frekwensi sebanyak 31 responden $(36,90 \%)$.

\section{Faktor Ekstrinsik}

Berdasarkan data faktor ekstrinsik terdapat 24 peryataan dengan skor 24 - 96. Dari analisis data dalam faktor ekstrinsik diperoleh skor terendah (minimum) 61, skor tertinggi (maksimum) 90, rerata (mean) 73,24, nilai tengah (median) 72,00 nilai yang sering muncul (mode) 72, standar defiasi (SD) 6,22. 
Tabel 7

\begin{tabular}{|c|c|c|c|c|}
\hline & $\begin{array}{r}\text { Iasil Ana } \\
\mathrm{Fa} \\
\end{array}$ & $\begin{array}{l}\text { lisis } \mathrm{Da} \\
\text { ktor Ek }\end{array}$ & $\begin{array}{l}\text { ta berda } \\
\text { trinsik }\end{array}$ & arkan \\
\hline o & Katagori & Rentang & & kuensi \\
\hline & Jawaban & skor & Absolut & $\begin{array}{l}\text { Persentase } \\
\quad(\%)\end{array}$ \\
\hline & Sangat & $\geq$ & 6 & $7,14 \%$ \\
\hline & Tinggi & 82,57 & & \\
\hline 2 & Tinggi & $\begin{array}{c}76,35- \\
82,56\end{array}$ & 16 & $19,04 \%$ \\
\hline 3 & Sedang & 70,13 - & 32 & $38,09 \%$ \\
\hline & & 76,34 & & \\
\hline 4 & Rendah & 63,91 - & 28 & $33,33 \%$ \\
\hline & & & & \\
\hline 5 & Sangat & $=$ & 2 & $2,38 \%$ \\
\hline & Rendah & 63,90 & & \\
\hline & Jumlah & & 84 & $100 \%$ \\
\hline
\end{tabular}

Berdasarkan hasil tersebut terlihat bahwa motivasi orang tua memasukkan putranya ke Sekolah Sepakbola Selabora di Fakultas Ilmu Keolahragaan Universitas Negeri Yogyakarta melalui faktor ekstrinsik dari 84 orang tua atau wali murid siswa di SSB Selabora adalah: 6 orang atau $(7,14 \%)$ masuk kategori sangat tinggi, 16 orang tua atau $(19,04 \%)$ masuk kategori tinggi, 32 orang tua atau $(38,09 \%)$ masuk kategori sedang, 28 orang tua atau $(33,33 \%)$ masuk kategori rendah dan 2 orang tua atau $(2,38 \%)$ masuk kategori sangat rendah.

Adapun jika digambarkan dalam bentuk diagram batang hasil penelitian dapat dilihat pada gambbar 5 sebagai berikut:

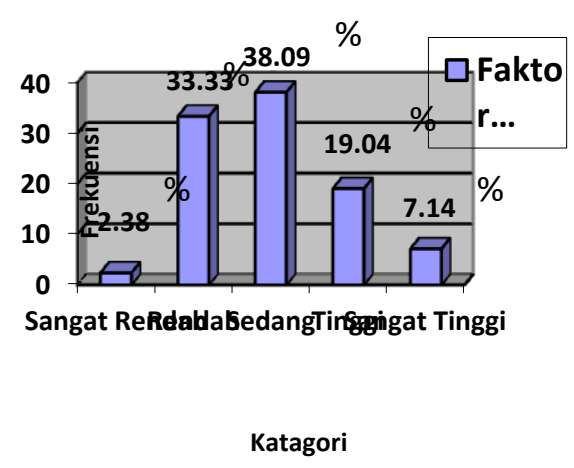

Gambar 5. Diagram Batang Motivasi Orang Tua Memasukkan Putranya ke Sekolah Sepakbola Selabora di Fakultas Ilmu Keolahragaan Universitas Negeri Yogyakarta berdasarkan Faktor Ekstrinsik

Motivasi adalah suatu kekuatan, baik dalam diri maupun dari luar seseorang yang mendorong untuk bertingkah laku untuk mencapai suatu tujuan. Motivasi terbagi menjadi dua faktor. Yaitu, faktor intrinsik dan faktor ekstrinsik. Faktor intrinsik merupakan suatu dorongan yang ada pada diri seseorang yang sifatnya berasal dari dalam diri seseorang atau individu tersebut. Sedangkan faktor ekstrinsik merupakan suatu dorongan yang ada pada seseorang yang sifatnya berasal dari luar seseorang atau luar individu.

Berdasarkan data hasil penelitian, maka dapat diketahui bahwa motivasi orang tua memasukkan putranya ke sekolah sepakbola Selabora di Fakultas Ilmu Keolahragaan Universitas Negeri Yogyakarta dari 84 orang tua atau wali murid siswa di SSB Selabora termasuk dalam katagori sedang $(42,86 \%)$. Hal ini ditunjukkan dengan mean atau rerata yang diperoleh sebesar 139,37 yang 
berada pada interval 133,69 s.d 144,78 . Dari 84 orang tua atau wali murid siswa di SSB Selabora adalah: $9(10,71 \%)$ orang tua menyatakan sangat tinggi, $15(17,86 \%)$ orang tua menyatakan tinggi, $36 \quad(42,86 \%)$ orang tua menyatakan sedang, 18 $(21,43 \%)$ orang tua menyatakan rendah dan $6(7,14 \%)$ orang tua menyatakan sangat rendah.

Analisis terhadap faktor intrinsik, ditemukan hasil bahwa motivasi orang tua dalam memasukkan putranya ke SSB Selabora di FIK UNY berada dalam katagori sedang $(36,90 \%)$. Dari 84 orang tua atau wali murid siswa di SSB Selabora menyatakan bahwa: $3(3,57 \%)$ orang tua menyatakan sangat tinggi, 22 $(26,19 \%)$ orang tua menyatakan tinggi, $31(36,90 \%)$ orang tua menyatakan sedang, 22 (26,19\%) orang tua menyatakan rendah dan 6 $(7,14 \%)$ orang tua menyatakan sangat rendah.

Analisis terhadap faktor ekstrinsik, mayoritas motivasi orang tua memasukkan putranya ke SSB Selabora di FIK UNY berada dalam katagori sedang $(38,09 \%)$. Dari 84 orang tua atau wali murid siswa di SSB Selabora menyatakan bahwa: 6 $(7,14 \%)$ orang tua menyatakan sangat tinggi, $16(19,04 \%)$ orang tua menyatakan tinggi, $32 \quad(38,09 \%)$ orang tua menyatakan sedang, 28 $(33,33 \%)$ orang tua menyatakan rendah dan $2(2,38 \%)$ orang tua menyatakan sangat rendah.

Berdasarkan dari hasil penelitian di atas tergambar bahwa motivasi orang tua dalam memasukkan putranya ke SSB Selabora pada faktor intrinsik lebih besar di banding dengan faktor ekstrinsik.

\section{E. KESIMPULAN}

Berdasarkan hasil penelitian dan pembahasan yang telah diuraikan dalam bab sebelumnya, penulis dapat menarik kesimpulan sebagai berikut: Dari total data 84 orang tua atau wali murid siswa di SSB Selabora (responden) menyatakan: 9 orang tua atau $(10,71 \%)$ masuk kategori sangat tinggi, 15 orang tua atau $(17,86 \%)$ masuk kategori tinggi, 36 orang tua atau $(42,86 \%)$ masuk kategori sedang, 18 orang tua atau $(21,43 \%)$ masuk kategori rendah dan 6 orang tua atau $(7,14 \%)$ masuk kategori sangat rendah. Hal ini ditunjukkan dengan mean atau rerata yang diperoleh sebesar 139,37 yang berada pada interval 133,69 s.d 144,78 .

Berdasarkan hasil tersebut dapat disimpulkan bahwa motivasi orang tua memasukkan putranya ke Sekolah Sepakbola Selabora di Fakultas Ilmu Keolahragaan Universitas Negeri Yogyakarta sebagian besar berada dalam katagori sedang yaitu 36 orang tua $(42,86 \%)$.

\section{F. DAFTAR PUSTAKA}

Anas Sudijono. 2006. Pengantar Statistik Pendidikan. PT Raja Grafindo Persada. Jakarata.

Dwi Sisiwoyo dkk. 2008. Ilmu Pendidikan. UNY Press. Yogyakarata.

Hamzah B. Uno. 2008. Teori Motivasi dan Pengukurannya. Bumi Aksara. Jakarta.

Monty P. Satiadarma. 2000. DasarDasar Psikologi Olahraga. Pustaka Sinar Harapan. Jakarta.

Ratna Yudhawati \& Dany Haryanto. 2011. Teori-Teori Dasar 
Psikologi Pendidikan. PT Prestasi Pustakarya. Jakarta.

Saifuddin Azwar. 2005. Metode Penelitian. Pustaka Pelajar Offset. Yogyakarta.

Sardiman. 1992. Interaksi dan Motivasi Belajar Mengajar. Rajawali. Jakarta.

Singgih D Gunarsa. 2004. Psikologi Olagraga Prestasi. PT BPK Gunung Mulia. Jakarta.

Sucipto dkk. 2000. Sepak Bola. FIK UNY. Yogyakarta.

Sugiyono. 2009. Metode Penelitian Kuantitatif Kualitatif dan R \& D. Alfabeta. Bandung.
Suharsimi Arikunto. 1993. Prosedur Penelitian. PT Rineka Cipta. Jakarta.

Sutrisno Hadi. 1991. Analisis Butir untuk Instrumen, Angket, Tes dan Skala Nilai dengan Basica. Andi Offset. Yogyakarta.

Wahyu Prihandono. 2008. Motivasi orang tua dalam memasukkan anaknya ke sekolah sepakbola (SSB) ankatan muda sayegan (AMS). Skripsi.: FIK UNY. Yogyakarta. 